\title{
Highly Efficient 2,3-Butanediol Production by Bacillus licheniformis via Complex Optimization of Nutritional and Technological Parameters
}

\author{
Lidia Tsigoriyna ${ }^{1} \mathbb{D}$, Dimitar Ganchev ${ }^{1}$, Penka Petrova ${ }^{2}\left(\mathbb{D}\right.$ and Kaloyan Petrov ${ }^{1, *(D)}$ \\ 1 Institute of Chemical Engineering, Bulgarian Academy of Sciences, 1113 Sofia, Bulgaria; \\ lidinka29@gmail.com (L.T.); d.ganchev97@gmail.com (D.G.) \\ 2 Institute of Microbiology, Bulgarian Academy of Sciences, 1113 Sofia, Bulgaria; pepipetrova@yahoo.com \\ * Correspondence: kaloian04@yahoo.com
}

check for updates

Citation: Tsigoriyna, L.; Ganchev, D.; Petrova, P.; Petrov, K. Highly Efficient 2,3-Butanediol Production by Bacillus licheniformis via Complex

Optimization of Nutritional and Technological Parameters.

Fermentation 2021, 7, 118. https://

doi.org/10.3390/fermentation7030118

Academic Editors: Nhuan Nghiem and Tae Hyun Kim

Received: 16 June 2021

Accepted: 14 July 2021

Published: 16 July 2021

Publisher's Note: MDPI stays neutral with regard to jurisdictional claims in published maps and institutional affiliations.

Copyright: (c) 2021 by the authors. Licensee MDPI, Basel, Switzerland. This article is an open access article distributed under the terms and conditions of the Creative Commons Attribution (CC BY) license (https:/ / creativecommons.org/licenses/by/ $4.0 /)$.

\begin{abstract}
Butanediol (2,3-BD) is a reagent with remarkable commercial use as a platform chemical in numerous industries. The present study aims to determine the capabilities of non-pathogenic and cellulolytic Bacillus licheniformis 24 as a 2,3-BD producer. By applying the Plackett-Burman design and response surface methodology through central composite design (CCD), a complex optimization of medium and process parameters was conducted. Thus, among ten studied factors of medium content, four components were evaluated with a significant positive effect on 2,3-BD formation. Their optimal values for 2,3-BD production (yeast extract, $13.38 \mathrm{~g} / \mathrm{L}$; tryptone, $6.41 \mathrm{~g} / \mathrm{L} ; \mathrm{K}_{2} \mathrm{HPO}_{4}, 4.2 \mathrm{~g} / \mathrm{L}$; $\left.\mathrm{MgSO}_{4}, 0.32 \mathrm{~g} / \mathrm{L}\right)$, as well as the optimal temperature $\left(37.8^{\circ} \mathrm{C}\right), \mathrm{pH}(6.23)$ and aeration rate $(3.68 \mathrm{vvm})$ were predicted by CCD experiments and validated in a series of batch processes. In optimized batch fermentation of $200 \mathrm{~g} / \mathrm{L}$ of glucose $91.23 \mathrm{~g} / \mathrm{L}$ of 2,3-BD was obtained, with the overall productivity of $1.94 \mathrm{~g} / \mathrm{L} / \mathrm{h}$ and yield of $0.488 \mathrm{~g} / \mathrm{g}$. To reveal the maximum 2,3-BD tolerance of B. licheniformis 24, fed-batch fermentation was carried out. The obtained $138.8 \mathrm{~g} / \mathrm{L}$ of 2,3-BD with a yield of $0.479 \mathrm{~g} / \mathrm{g}$ and productivity of $1.16 \mathrm{~g} / \mathrm{L} / \mathrm{h}$ ranks the strain among the best 2,3-BD producers.
\end{abstract}

Keywords: 2,3-butanediol; Bacillus licheniformis; Plackett-Burman design; response surface methodology

\section{Introduction}

The possibility of microbial synthesis of the bivalent alcohol 2,3-butanediol (2,3-BD) was investigated for the first time more than a century ago by Harden and Walpole in Klebsiella pneumoniae and by Donker in Paenibacillus polymyxa [1,2]. Although its future use was only speculative at that time, today, the 2,3-BD market is notably fast-growing and is expected to reach USD 220 million in 2027 [3]. The most indispensable application of 2,3-BD is in the chemical, pharmaceutical and food industries, as a starting reagent in the production of rubber, solvents, varnishes, polyesters, polyurethanes and methacrylate. It is also a common constituent of liquid fuels, antifreeze, cosmetic products, drugs, antiperspirants and ointments [4-6]. A recent study reports 2,3-BD integration into biodegradable biofilms [7]. However, the emerging ecological problems, fossil fuel exhaustion and climate changes impose the development of biotechnologies for a bio-based alternative of 2,3-BD chemical synthesis despite cost competitiveness issues [8,9].

Current strategies for increased microbial production of 2,3-BD include (i) isolation of new bacterial producers, preferably non-pathogenic, that can utilize cheap, renewable and non-nutritional substrates, (ii) development of engineered strains that may produce optically pure isomers and (iii) selection of strains amenable to process optimization for increased 2,3-BD titer, yield and productivity. The "generally regarded as safe" (GRAS) 2,3-BD producers are the most desirable on an industrial scale; therefore, Paenibacillus polymyxa [10,11], Bacillus subtilis [12,13], B. amyloliquefaciens [14,15], B. pumilus, B. siamensis [16], B. vallismortis [17], B. licheniformis, B. velezensis, B. toyonensis and B. safensis have been evaluated as particularly promising [18-21]. 
However, B. licheniformis combines the greatest number of benefits. It has the potential to convert a variety of substrates into 2,3-BD, such as starch and corncob hydrolyzates [22,23], inulin [24] and most of the sugars included in plant biomass, such as glucose, cellobiose, galactose, mannose, xylose and arabinose. Although several attempts to optimize the medium content and culture conditions for B. licheniformis have been made, several unresolved issues with the species and the peculiar nature of the process remain to be studied in more detail. First, several process optimizations refer to thermophilic B. licheniformis strains $[16,25]$, but information concerning the optimal conditions for high 2,3-BD production by mesophilic representatives is scarce. Second, it has to be noted that 2,3-BD is obtained via mixed acid fermentation yielding multiple products and the majority of them are undesirable and decrease the 2,3-BD yield. Beside 2,3-BD and its precursor, acetoin, some $B$. licheniformis strains produce mainly acetic acid and ethanol as by-products [26], while others secrete also lactate, formate and glycerol [27]. Therefore, different optimization approaches are required to decrease the specific spectrum of final metabolites produced by each industrial strain.

On the other hand, oxygen supply is a critical factor for acetoin and 2,3-BD interconversion. High levels of dissolved oxygen lead to acetoin synthesis, while lower levels favor 2,3-BD synthesis [21]. In addition, 2,3-BD can also serve as a carbon source for $B$. licheniformis at diminished glucose concentrations [28]. That is why a fed-batch process performance that requires additional improvement is frequently applied $[16,20]$.

In our recent study, we revealed that Bulgarian isolate B. licheniformis 24 possesses particularly high 2,3-BD productivity using glucose, mannose and cellobiose, reaching 0.77 , 0.64 and $0.46 \mathrm{~g} / \mathrm{L} / \mathrm{h}$, respectively [18]. 2,3-BD yield from glucose was $83 \%$ of the theoretical maximum without any process optimization. Moreover, the strain was able to maintain low levels of acetoin even when the substrate was depleted and displayed significant natural extracellular cellulase activity [18]. Since B. licheniformis 24 is particularly promising as a producer of 2,3-BD from cellulose-containing substrates, we focused on detailed process optimization to obtain the highest production values from glucose. The purpose of the study was achieved by the use of Plackett-Burman and central composite design (CCD) for medium optimization and response surface design methodology for optimization of process parameters applied to both batch and fed-batch operation performance. The obtained record 2,3-BD amount also elucidates the maximal tolerance of the strain to this target metabolite.

\section{Materials and Methods}

\subsection{Bacterial Strain and Basal Medium}

B. licheniformis strain 24 was isolated from a soil sample collected near the Yantra river, Bulgaria, and is stored in the Microbial culture collection of the Institute of Microbiology, Bulgarian Academy of Sciences. It was identified by $16 \mathrm{~S}$ rDNA sequencing (NCBI GenBank accession no. MK461938).

As a basic nutrient medium in the optimization experiments, we used the medium initially developed for P. polymyxa by Okonkwo et al. [29], modified by Petrova et al. [18], with the following content (g/L): glucose, 20-100; yeast extract, 5; tryptone, 5; $\left(\mathrm{NH}_{4}\right)_{2}$ $\mathrm{SO}_{4}, 3 ; \mathrm{KH}_{2} \mathrm{PO}_{4}, 3.5 ; \mathrm{K}_{2} \mathrm{HPO}_{4}, 2.75 ; \mathrm{MgSO}_{4}, 0.2 ;$ ammonium acetate, $1.5 ; \mathrm{CoCl}_{2} 6 \mathrm{H}_{2} \mathrm{O}$, 0.09; 3-morpholino propane sulfonic acid (MOPS), 10; salt solution, $3 \mathrm{~mL}$ per liter. The salt solution contained (g/L): $\mathrm{FeSO}_{4}, 0.4 ; \mathrm{H}_{3} \mathrm{BO}_{3}, 0.8 ; \mathrm{CuSO}_{4} \cdot 5 \mathrm{H}_{2} \mathrm{O}, 0.04 ; \mathrm{NaMoO}_{4} \cdot 2 \mathrm{H}_{2} \mathrm{O}, 0.04$; $\mathrm{MnCl}_{2} \cdot 4 \mathrm{H}_{2} \mathrm{O}, 5.0 ; \mathrm{ZnSO}_{4} \cdot 7 \mathrm{H}_{2} \mathrm{O}, 0.1 ; \mathrm{Co}\left(\mathrm{NO}_{3}\right)_{2} \cdot 6 \mathrm{H}_{2} \mathrm{O}, 0.08 ; \mathrm{CaCl}_{2} \cdot 2 \mathrm{H}_{2} \mathrm{O}, 1.0 ;$ Biotin, 0.01 .

\subsection{Cultivation Conditions}

The experiments for media optimization (Plackett-Burman design and CCD) were performed in $500 \mathrm{~mL}$ Erlenmeyer flasks with $100 \mathrm{~mL}$ of media containing $100 \mathrm{~g} / \mathrm{L}$ glucose at $37^{\circ} \mathrm{C}$ and $200 \mathrm{rpm}$, on a rotary shaker (New Brunswick, San Diego, CA, USA). As an inoculum, we used overnight culture grown in $500 \mathrm{~mL}$ flasks with $50 \mathrm{~mL}$ of basal medium containing $20 \mathrm{~g} / \mathrm{L}$ of glucose, at $37^{\circ} \mathrm{C}, 200 \mathrm{rpm}$, on a rotary shaker. The inoculum was 
grown to $\mathrm{OD}=2.400$ (measured at wavelength $\lambda=600 \mathrm{~nm}$ ); its amount was $2 \%$ for the Plackett-Burman and $1 \%$ for the CCD experiments.

Batch fermentations for process parameter optimization and the fed-batch with optimized parameters were conducted in a stirred $1 \mathrm{~L}$ fermenter (Biostat ${ }^{\circledR}$ A plus, Sartorius Stedim Biotech, Gottingen, Germany) additionally equipped with bumpers to provide more aerobic conditions. Likewise, an additional air pump and rotameter were used to ensure higher levels of airflow supply. The $\mathrm{pH}$ was controlled by the addition of $6 \mathrm{M} \mathrm{NaOH}$ or $5 \mathrm{M} \mathrm{HCl}$. Batch processes were carried out using the medium with optimized content, supplemented with $200 \mathrm{~g} / \mathrm{L}$ of glucose and $10 \%$ inoculum (grown to $\mathrm{OD}_{600}=2.400$ ), thus corresponding to an initial glucose concentration of 185-187 g/L. In fed-batch fermentation, the additional substrate amount was added as portions of filter-sterilized glucose stock with a concentration of $700 \mathrm{~g} / \mathrm{L}$.

\subsection{Screening for Significant Factors in Media Composition}

The Plackett-Burman design experiment was applied to estimate the significance of each compound of the nutrient medium [13,30]. An advantage of this design is the ability to study a large number of variables through a relatively small number of experiments. The influence of 10 components of the nutrient medium was studied, as corn steep liquor was additionally added to the 9 components of the basal medium to possibly replace the more expensive nitrogen sources yeast extract and tryptone (Table 1). A 15-run design including 3 central points and 12 cube points on two levels $(+1,-1)$ was used. The influence of each factor on 2,3-BD production was described by the first-degree (linear) polynomial Equation (1):

$$
Y=\beta_{0}+\sum \beta_{i} X_{i}
$$

where $Y$ is the predicted response, $\beta_{0}$ is the intercept term, $\beta_{i}$ is the linear coefficient and $X_{i}$ is an independent variable.

Table 1. Media components selected for variation and their experimental range for 2,3-BD production using a ten-factor Plackett-Burman design.

\begin{tabular}{ccccc}
\hline Variables (Media Components) & Code & \multicolumn{3}{c}{ Experimental Levels } \\
\cline { 3 - 5 } & & $-\mathbf{1}$ & $\mathbf{0}$ & $\mathbf{1}$ \\
\hline Yeast extract $(\mathrm{g} / \mathrm{L})$ & $X_{1}$ & 0 & 5 & 10 \\
Tryptone $(\mathrm{g} / \mathrm{L})$ & $X_{2}$ & 0 & 5 & 10 \\
$\left(\mathrm{NH}_{4}\right)_{2} \mathrm{SO}_{4}(\mathrm{~g} / \mathrm{L})$ & $X_{3}$ & 1 & 3 & 5 \\
$\mathrm{KH}_{2} \mathrm{PO}_{4}$ (g/L) & $X_{4}$ & 2 & 3.5 & 5 \\
$\mathrm{~K}_{2} \mathrm{HPO}_{4}(\mathrm{~g} / \mathrm{L})$ & $X_{5}$ & 2 & 2.75 & 3.5 \\
$\mathrm{MgSO}_{4}(\mathrm{~g} / \mathrm{L})$ & $X_{6}$ & 0.1 & 0.2 & 0.3 \\
Ammonium acetate (g/L) & $X_{7}$ & 0.5 & 1.5 & 2.5 \\
Corn steep liquor (g/L) & $X_{8}$ & 0 & 10 & 20 \\
Salt solution (\%) & $X_{9}$ & 1 & 3 & 5 \\
MOPS $^{\text {a }}$ (g/L) & $X_{10}$ & 0 & 5 & 10 \\
\hline
\end{tabular}

a MOPS, 3-morpholino propane sulfonic acid.

\subsection{Media Optimization by Response Surface Design Methodology}

The response surface methodology via CCD experiment was used to determine the optimal values of the components of the medium with significant influence on 2,3-BD production. According to the results obtained from the Plackett-Burman design, the variables were the following: yeast extract $\left(X_{1}\right)$; tryptone $\left(X_{2}\right) ; \mathrm{K}_{2} \mathrm{HPO}_{4}\left(X_{5}\right) ; \mathrm{MgSO}_{4}\left(X_{6}\right)$. The four variables were tested at 5 levels $(-2,-1,0,+1,+2)$, in a matrix containing 31-run design with 7 central, 8 axial and 16 cube points. The variables levels and the corresponding values are shown in Table 2. 
Table 2. Media components selected for variation and their experimental range for 2,3-BD production using a four-factor CCD.

\begin{tabular}{cccccc}
\hline Factors & \multicolumn{5}{c}{ Experimental Levels } \\
\cline { 2 - 6 } (Variable) & $-\boldsymbol{\alpha}^{*}$ & $-\mathbf{1}$ & $\mathbf{0}$ & $\mathbf{1}$ & $\boldsymbol{\alpha}^{*}$ \\
\hline Yeast extract $(\mathrm{g} / \mathrm{L})\left(X_{1}\right)$ & 5 & 7.5 & 10 & 12.5 & 15 \\
Tryptone (g/L) $\left(X_{2}\right)$ & 5 & 7.5 & 10 & 12.5 & 15 \\
$\mathrm{~K}_{2} \mathrm{HPO}_{4}(\mathrm{~g} / \mathrm{L})\left(X_{5}\right)$ & 2.5 & 3.0 & 3.5 & 4.0 & 4.5 \\
$\mathrm{MgSO}_{4}(\mathrm{~g} / \mathrm{L})\left(X_{6}\right)$ & 0.2 & 0.25 & 0.3 & 0.35 & 0.4 \\
\hline${ }^{* \alpha=2 .}$ & &
\end{tabular}

An investigation of the effect of variables on 2,3-BD production was performed by a regression model, using the following second-degree polynomial Equation (2):

$$
Y=\beta_{0}+\sum \beta_{i} X_{i}+\sum \beta_{i i} X_{i}^{2}+\sum \beta_{i j} X_{i} X_{j}
$$

where $Y$ is the predicted response, $\beta_{0}$ is the intercept term, $\beta_{i}$ is the linear coefficient, $\beta_{i i}$ is the quadratic coefficient, $\beta_{i j}$ is the coefficient of interaction and $X_{i}$ and $X_{j}$ are independent variables.

\subsection{Process Parameter Optimization by Response Surface Design Methodology}

The most important process parameters-temperature, $\mathrm{pH}$ and aeration-were subjected to optimization by applying the same response surface methodology used for the optimization of media components [31,32]. In this case, a three-factor central composite design experiment was applied, as the three variables were set at 5 levels $(-1.682,-1,0,+1$, +1.682 ), in a matrix containing a total of 20 runs -6 central, 6 axial and 8 cube points. The relevant formula for the used regression model is the second-degree polynomial Equation (2). The coded levels of these 3 variables and their corresponding actual values are shown in Table 3.

Table 3. Process parameters selected for variation and their experimental range for 2,3-BD production using a three-factor central composite design.

\begin{tabular}{cccccc}
\hline Factors & \multicolumn{5}{c}{ Experimental Levels } \\
\cline { 2 - 6 } (Variable) & $-\boldsymbol{\alpha}^{*}$ & $\mathbf{- 1}$ & $\mathbf{0}$ & $\mathbf{1}$ & $\boldsymbol{\alpha}^{*}$ \\
\hline $\mathrm{t}\left({ }^{\circ} \mathrm{C}\right)\left(X_{1}\right)$ & 28.9546 & 31 & 34 & 37 & 39.0454 \\
$\mathrm{pH}\left(\mathrm{X}_{2}\right)$ & 5.1591 & 5.5 & 6.0 & 6.5 & 6.8409 \\
Aeration rate $(\mathrm{vvm})\left(X_{3}\right)$ & 0.3182 & 1.0 & 2.0 & 3.0 & 3.6818 \\
\hline
\end{tabular}

\subsection{Analytical Methods}

Cell growth was estimated by viable cells counts (CFU, colony-forming units, per $\mathrm{mL}$ ) of decimal dilutions of samples, which were grown on Luria-Bertani (LB) agar plates. Glucose, lactic acid, glycerol, acetoin, 2,3-butanediol and ethanol amounts were quantified using the YL Instrument 9300 HPLC System (YL Instrument Co., Ltd., Anyang, Korea). The soluble components were analyzed by HPLC column Aminex HPX-87H (BioRad Laboratories, Hercules, CA, USA) at $65^{\circ} \mathrm{C}$. The mobile phase was $5 \mathrm{mmoL}$ of $\mathrm{H}_{2} \mathrm{SO}_{4}$ at a flow rate of $0.6 \mathrm{~mL} / \mathrm{min}$. All compounds were detected by RI detector (YL 9170 RI Detector) as the quantification of lactic acid and acetoin was confirmed by a UV detector (YL9120 UV/Vis detector) at wavelengths of 210 and $190 \mathrm{~nm}$, respectively. All standard substances were purchased from Merck KgaA, Darmstadt, Germany.

The statistical analyses were accomplished using the Minitab 17 software of Minitab Inc. (State College, PA, USA), www.minitab.com. 


\section{Results}

\subsection{Media Optimization}

\subsubsection{Screening for Significant Factors in Media Composition}

Ten nutrient medium components were studied in order to assess their significance for 2,3-BD production (Table 1). As a response, according to the design of Plackett-Burman, the concentration of 2,3-BD after $24 \mathrm{~h}$ of fermentation was used. The statistical analysis of the experimental results showed that, within the defined ranges, the yeast extract, $\mathrm{K}_{2} \mathrm{HPO}_{4}$, $\mathrm{MgSO}_{4}$ and the tryptone had a significant positive effect, the corn steep liquor had a significant negative effect and the other variables had no significant effect on the 2,3-BD formation ( $p$ value $>0.05$ ). The results shown in Table 4 reveal that the most influencing factor appeared to be the yeast extract with a linear coefficient of 6.181 and $p$ value of 0.001 , followed by the corn steep liquor $(-5.2680, p=0.001), \mathrm{K}_{2} \mathrm{HPO}_{4}(4.731, p=0.002), \mathrm{MgSO}_{4}$ $(2.758, p=0.008)$ and the tryptone $(1.421, p=0.047)$.

Table 4. Estimated coded coefficients from the linear regression model for 2,3-BD production in a ten-factor Plackett-Burman design.

\begin{tabular}{ccccc}
\hline Source & Effect & Coefficient & $\boldsymbol{T}$ Value & $p$ Value \\
\hline Constant & & 10.477 & 24.09 & 0.000 \\
Yeast extract $\left(X_{1}\right)$ & 12.362 & 6.181 & 14.25 & $0.001^{\mathrm{a}}$ \\
Tryptone $\left(X_{2}\right)$ & 2.842 & 1.421 & 3.28 & $0.047^{\mathrm{a}}$ \\
$\left(\mathrm{NH}_{4}\right)_{2} \mathrm{SO}_{4}\left(X_{3}\right)$ & -0.465 & -0.233 & -0.54 & 0.629 \\
$\mathrm{KH}_{2} \mathrm{PO}_{4}\left(X_{4}\right)$ & -1.028 & -0.514 & -1.19 & 0.321 \\
$\mathrm{~K}_{2} \mathrm{HPO}_{4}\left(X_{5}\right)$ & 9.462 & 4.731 & 10.91 & $0.002^{\mathrm{a}}$ \\
$\mathrm{MgSO}_{4}\left(\mathrm{X}_{6}\right)$ & 5.515 & 2.758 & 6.36 & $0.008^{\mathrm{a}}$ \\
Ammonium acetate $\left(X_{7}\right)$ & -1.538 & -0.769 & -1.77 & 0.174 \\
Corn steep liquor $\left(X_{8}\right)$ & -10.535 & -5.268 & -12.15 & $0.001^{\mathrm{b}}$ \\
Salt solution $\left(X_{9}\right)$ & -2.395 & -1.197 & -2.76 & 0.070 \\
MOPS $\left(X_{10}\right)$ & 1.145 & 0.573 & 1.32 & 0.278 \\
\hline
\end{tabular}

a Significant positive effect; ${ }^{\mathrm{b}}$ significant negative effect.

The variance analysis showed that the $R^{2}$ value (coefficient of determination) of the model is $99.53 \%$, indicating that the model fits the experimental data almost completely. Likewise, the computed $p$ value (0.003) and "Lack-of-Fit" value (0.741) of the model also suggest the statistical significance of the regression equation.

The four components (yeast extract, $\mathrm{K}_{2} \mathrm{HPO}_{4}, \mathrm{MgSO}_{4}$ and tryptone) possessing a significant positive effect on 2,3-BD production were selected for further investigation of their optimal values. Corn steep liquor and MOPS were excluded from the media composition due to their significant negative effect in the range $0-20 \mathrm{~g} / \mathrm{L}$ and lack of influence in the range $0-10 \mathrm{~g} / \mathrm{L}$.

\subsubsection{Optimization of the Values of the Significant Factors in Media Composition}

The significant factors were optimized for 2,3-BD production using the CCD experiment. The randomized design matrix is shown in Table 5. 
Table 5. Real values of the four variables $\left(X_{1}, X_{2}, X_{5}\right.$ and $\left.X_{6}\right)$ and the observed response (2,3-BD concentration after $24 \mathrm{~h}$ of fermentation) using CCD for media optimization. $X_{1}$, yeast extract $(\mathrm{g} / \mathrm{L})$; $\mathrm{X}_{2}$, tryptone $(\mathrm{g} / \mathrm{L}) ; \mathrm{X}_{5}, \mathrm{~K}_{2} \mathrm{HPO}_{4}(\mathrm{~g} / \mathrm{L}) ; \mathrm{X}_{6}, \mathrm{MgSO}_{4}(\mathrm{~g} / \mathrm{L})$.

\begin{tabular}{|c|c|c|c|c|c|}
\hline \multirow[t]{2}{*}{ Run Order } & \multicolumn{4}{|c|}{ Experimental Values } & \multirow{2}{*}{$\begin{array}{c}2,3-B D \text { * } \\
(\mathrm{g} / \mathrm{L})\end{array}$} \\
\hline & $X_{1}$ & $X_{2}$ & $X_{5}$ & $X_{6}$ & \\
\hline 1 & 7.5 & 7.5 & 3.0 & 0.25 & 17.595 \\
\hline 2 & 12.5 & 7.5 & 3.0 & 0.25 & 18.990 \\
\hline 3 & 7.5 & 12.5 & 3.0 & 0.25 & 21.725 \\
\hline 4 & 12.5 & 12.5 & 3.0 & 0.25 & 20.680 \\
\hline 5 & 7.5 & 7.5 & 4.0 & 0.25 & 22.245 \\
\hline 6 & 12.5 & 7.5 & 4.0 & 0.25 & 24.955 \\
\hline 7 & 7.5 & 12.5 & 4.0 & 0.25 & 24.780 \\
\hline 8 & 12.5 & 12.5 & 4.0 & 0.25 & 23.130 \\
\hline 9 & 7.5 & 7.5 & 3.0 & 0.35 & 15.975 \\
\hline 10 & 12.5 & 7.5 & 3.0 & 0.35 & 20.665 \\
\hline 11 & 7.5 & 12.5 & 3.0 & 0.35 & 21.555 \\
\hline 12 & 12.5 & 12.5 & 3.0 & 0.35 & 22.870 \\
\hline 13 & 7.5 & 7.5 & 4.0 & 0.35 & 20.950 \\
\hline 14 & 12.5 & 7.5 & 4.0 & 0.35 & 25.305 \\
\hline 15 & 7.5 & 12.5 & 4.0 & 0.35 & 22.060 \\
\hline 16 & 12.5 & 12.5 & 4.0 & 0.35 & 25.150 \\
\hline 17 & 5.0 & 10.0 & 3.5 & 0.30 & 17.300 \\
\hline 18 & 15.0 & 10.0 & 3.5 & 0.30 & 23.170 \\
\hline 19 & 10.0 & 5.0 & 3.5 & 0.30 & 20.390 \\
\hline 20 & 10.0 & 15.0 & 3.5 & 0.30 & 25.140 \\
\hline 21 & 10.0 & 10.0 & 2.5 & 0.30 & 15.620 \\
\hline 22 & 10.0 & 10.0 & 4.5 & 0.30 & 23.850 \\
\hline 23 & 10.0 & 10.0 & 3.5 & 0.20 & 21.780 \\
\hline 24 & 10.0 & 10.0 & 3.5 & 0.40 & 21.465 \\
\hline 25 & 10.0 & 10.0 & 3.5 & 0.30 & 24.680 \\
\hline 26 & 10.0 & 10.0 & 3.5 & 0.30 & 24.595 \\
\hline 27 & 10.0 & 10.0 & 3.5 & 0.30 & 24.365 \\
\hline 28 & 10.0 & 10.0 & 3.5 & 0.30 & 23.820 \\
\hline 29 & 10.0 & 10.0 & 3.5 & 0.30 & 25.125 \\
\hline 30 & 10.0 & 10.0 & 3.5 & 0.30 & 24.340 \\
\hline 31 & 10.0 & 10.0 & 3.5 & 0.30 & 25.400 \\
\hline
\end{tabular}

* Mean values of duplicates.

The central points (level 0) of the experimental ranges for each variable in the CCD scheme were determined to correspond to their higher level (+1) in the Plackett-Burman design. As a response, we used the obtained concentration of 2,3-BD after $24 \mathrm{~h}$ of fermentation. The analysis of the variance revealed that the response surface regression model can explain $96.59 \%$ of the variation in response $\left(R^{2}=0.9659\right)$. According to Reddy et al. [31], values of $R^{2}>0.75$ indicate good model fitness. The $p$ value of the model $(<0.001)$ and "Lack-of-Fit" value (0.155) showed that the regression equation is suitable to describe the process of 2,3-BD production. The estimated coded coefficients of variables and their $p$ values are shown in Table 6. 
Table 6. Estimated coded coefficients from the regression model for 2,3-BD production in a four-factor CCD.

\begin{tabular}{ccccc}
\hline Source & Effect & Coefficient & $T$ Value & $p$ Value \\
\hline Constant & & 24.618 & 91.59 & $<0.001$ \\
Yeast extract $\left(X_{1}\right)$ & 2.217 & 1.108 & 7.63 & $<0.001$ \\
Tryptone $\left(X_{2}\right)$ & 2.064 & 1.032 & 7.11 & $<0.001$ \\
$\mathrm{~K}_{2} \mathrm{HPO}_{4}\left(X_{5}\right)$ & 3.748 & 1.874 & 12.91 & $<0.001$ \\
$\mathrm{MgSO}_{4}\left(X_{6}\right)$ & -0.017 & -0.008 & -0.06 & 0.955 \\
$X_{1}^{2}$ & -1.958 & -0.979 & -7.36 & $<0.001$ \\
$X_{2}^{2}$ & -0.693 & -0.347 & -2.61 & 0.019 \\
$X_{5}^{2}$ & -2.208 & -1.104 & -8.30 & $<0.001$ \\
$X_{6}{ }^{2}$ & -1.264 & -0.632 & -4.75 & $<0.001$ \\
$X_{1} X_{2}$ & -1.430 & -0.715 & -4.02 & 0.001 \\
$X_{1} X_{5}$ & 0.269 & 0.134 & 0.76 & 0.461 \\
$X_{1} X_{6}$ & 1.505 & 0.753 & 4.23 & 0.001 \\
$X_{2} X_{5}$ & -1.493 & -0.746 & -4.20 & 0.001 \\
$X_{2} X_{6}$ & 0.276 & 0.138 & 0.78 & 0.449 \\
$X_{5} X_{6}$ & -0.465 & -0.233 & -1.31 & 0.209
\end{tabular}

The presented data indicate that the model terms $X_{1}, X_{2}, X_{5}$, all quadratic terms, and the interaction terms $\mathrm{X}_{1} \mathrm{X}_{2}, \mathrm{X}_{1} \mathrm{X}_{6}$ and $\mathrm{X}_{2} \mathrm{X}_{5}$ have a significant effect on 2,3-BD production $(p<0.05)$. Thus, the second-degree polynomial Equation (2) takes the following form (3):

$Y=24.62+1.11 X_{1}+1.03 X_{2}+1.87 X_{5}-0.98 X_{1}^{2}-0.35 X_{2}^{2}-1.10 X_{5}^{2}-0.63 X_{6}^{2}-0.72 X_{1} X_{2}$ $+0.75 X_{1} X_{6}-0.75 X_{2} X_{5}$

The influence of the varied media components on 2,3-BD formation can be seen in three-dimensional response surface graphs, presented in Figure 1. They suggest that yeast extract and $\mathrm{K}_{2} \mathrm{HPO}_{4}$ are the most influencing parameters. The response optimization procedure predicts a maximum 2,3-BD production $(Y)$ of $25.825 \mathrm{~g} / \mathrm{L}$ at the following variable settings: yeast extract $\left(X_{1}\right), 13.38 \mathrm{~g} / \mathrm{L}$; tryptone $\left(X_{2}\right), 6.41 \mathrm{~g} / \mathrm{L} ; \mathrm{K}_{2} \mathrm{HPO}_{4}\left(X_{5}\right)$, $4.20 \mathrm{~g} / \mathrm{L} ; \mathrm{MgSO}_{4}\left(X_{6}\right), 0.32 \mathrm{~g} / \mathrm{L}$.

\subsubsection{Experimental Verification of the Model}

In order to verify the reliability of the model, a set of experiments with predicted optimal parameter values were performed. In these conditions, the observed concentration of 2,3-BD after $24 \mathrm{~h}$ of fermentation was $25.74 \pm 0.8 \mathrm{~g} / \mathrm{L}$ (in triplicate trials). This experimentally obtained value is very close to the predicted one of $25.825 \mathrm{~g} / \mathrm{L}$. Therefore, the regression equation quite accurately describes the changes in 2,3-BD production as a function of media content. The completely optimized medium had the following composition (g/L): yeast extract, 13.38; tryptone, 6.41; $\mathrm{K}_{2} \mathrm{HPO}_{4}, 4.2 ; \mathrm{MgSO}_{4}, 0.32 ;\left(\mathrm{NH}_{4}\right)_{2} \mathrm{SO}_{4}, 1$; $\mathrm{KH}_{2} \mathrm{PO}_{4}, 3.5$; ammonium acetate, $2.5 ; \mathrm{CoCl}_{2} \times 6 \mathrm{H}_{2} \mathrm{O}, 0.09$; salt solution, $3 \mathrm{~mL} / \mathrm{L}$. 


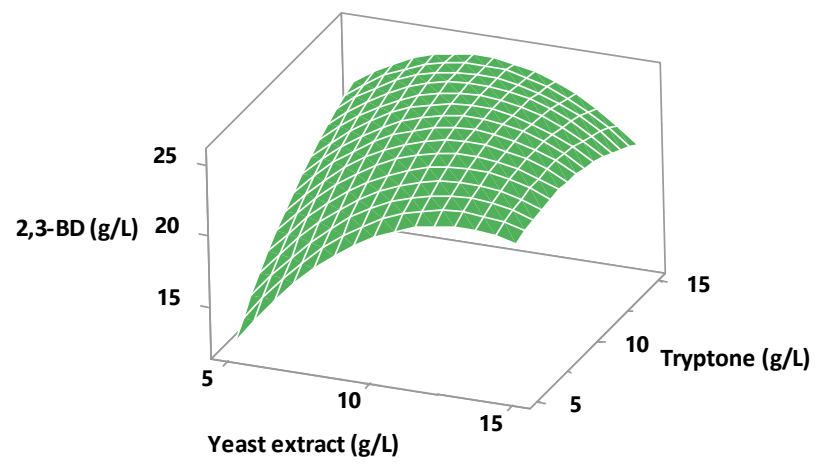

Hold values: $\mathrm{K}_{2} \mathrm{HPO}_{4}, 3.5 \mathrm{~g} / \mathrm{L} ; \mathrm{MgSO}_{4}, 0.3 \mathrm{~g} / \mathrm{L}$.

(a)

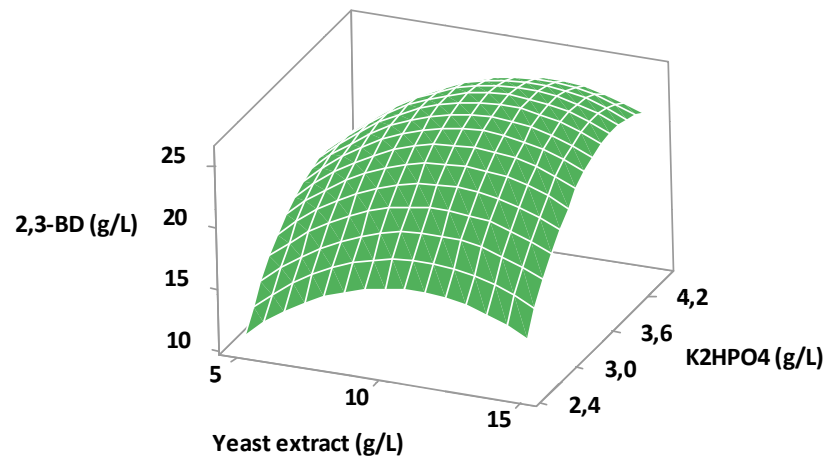

Hold values: tryptone, $10 \mathrm{~g} / \mathrm{L} ; \mathrm{MgSO}_{4}, 0.3 \mathrm{~g} / \mathrm{L}$.

(c)

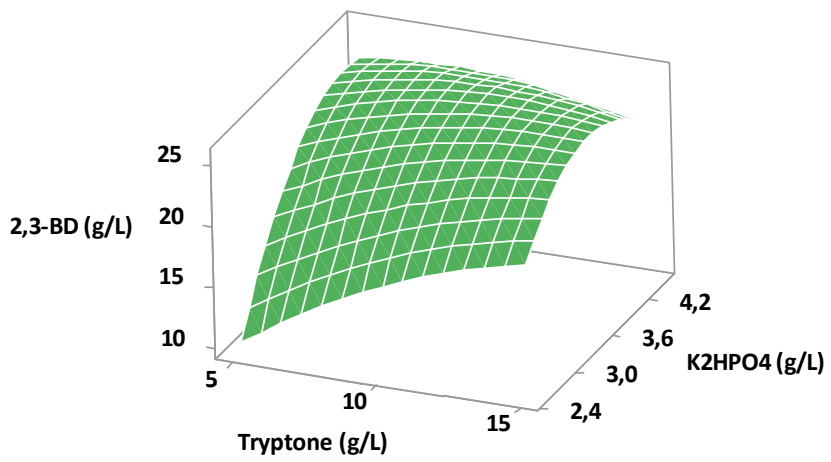

Hold values: yeast extract, $10 \mathrm{~g} / \mathrm{L} ; \mathrm{MgSO}_{4}, 0.3 \mathrm{~g} / \mathrm{L}$.

(e)

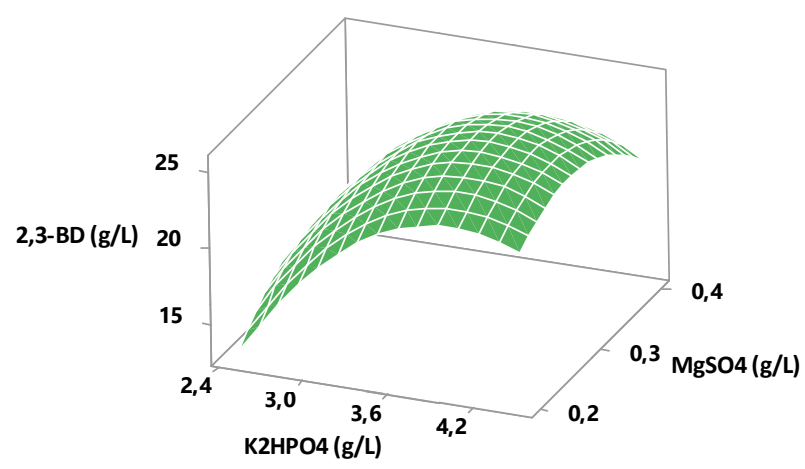

Hold values: yeast extract, $10 \mathrm{~g} / \mathrm{L}$; tryptone, $10 \mathrm{~g} / \mathrm{L}$.

(b)

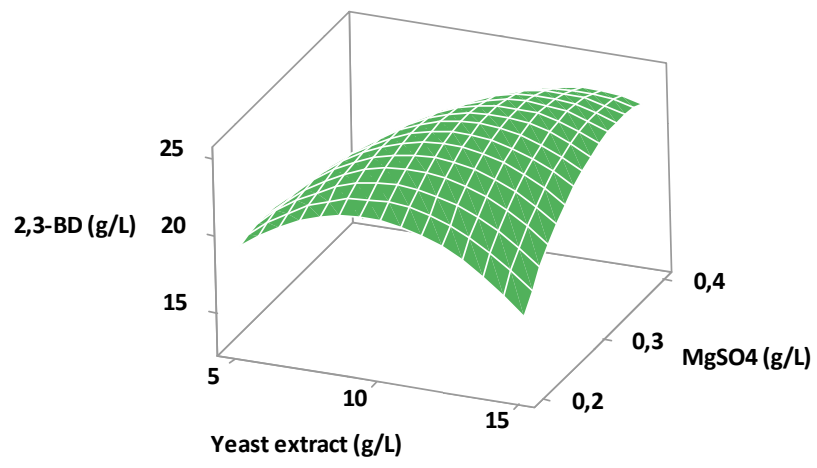

Hold values: tryptone, $10 \mathrm{~g} / \mathrm{L} ; \mathrm{K}_{2} \mathrm{HPO}_{4}, 3.5 \mathrm{~g} / \mathrm{L}$.

(d)

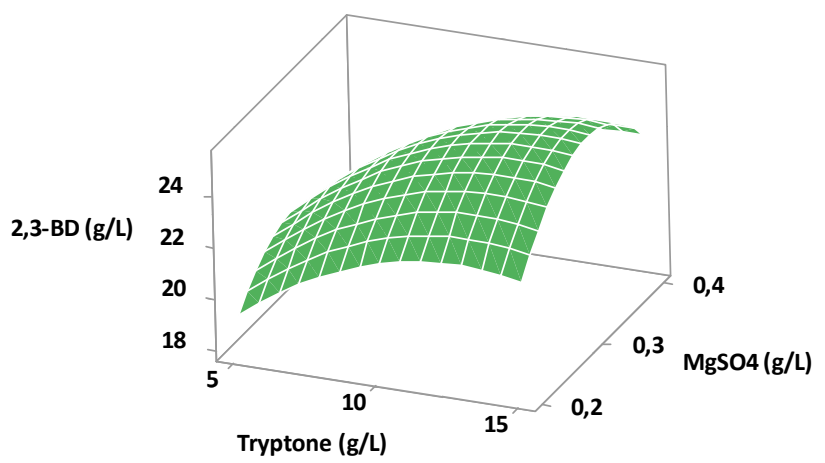

Hold values: yeast extract, $10 \mathrm{~g} / \mathrm{L} ; \mathrm{K}_{2} \mathrm{HPO}_{4}, 3.5 \mathrm{~g} / \mathrm{L}$.

(f)

Figure 1. Response surface graphs of 2,3-BD production after $24 \mathrm{~h}$ of fermentation: (a) influence of yeast extract and tryptone; (b) influence of $\mathrm{K}_{2} \mathrm{HPO}_{4}$ and $\mathrm{MgSO}_{4} ;(\mathbf{c})$ influence of yeast extract and $\mathrm{K}_{2} \mathrm{HPO}_{4} ;(\mathbf{d})$ influence of yeast extract and $\mathrm{MgSO}_{4} ;(\mathbf{e})$ influence of tryptone and $\mathrm{K}_{2} \mathrm{HPO}_{4} ;(\mathbf{f})$ influence of tryptone and $\mathrm{MgSO}_{4}$.

\subsection{Process Parameter Optimization}

\subsubsection{Optimization of the Process Parameters}

The optimization of the process parameters was carried out in series of batch experiments performed with an optimized medium containing $200 \mathrm{~g} / \mathrm{L}$ of glucose. Three parameters were subjected to optimization: temperature, $\mathrm{pH}$ and aeration flow. The response surface methodology was applied, following the scheme of the CCD experiment. The maximum concentration of 2,3-BD obtained during the process was chosen for the response. The design matrix and the observed responses are presented in Table 7. 
Table 7. Real values of the three variables $\left(X_{1}, X_{2}\right.$ and $\left.X_{3}\right)$ and the observed response (2,3-BD concentration) using $\mathrm{CCD}$ for process parameters optimization. $X_{1}$, temperature $\left({ }^{\circ} \mathrm{C}\right) ; \mathrm{X}_{2}, \mathrm{pH} ; \mathrm{X}_{3}$, aeration rate (airflow supply in vvm).

\begin{tabular}{|c|c|c|c|c|c|c|}
\hline \multirow{2}{*}{$\begin{array}{c}\text { Run Order } \\
\text { (Randomized) }\end{array}$} & \multicolumn{3}{|c|}{ Factor Levels in Real Values } & \multirow{2}{*}{$\begin{array}{c}2,3-B^{a}{ }^{a} \\
(g / L)\end{array}$} & \multirow{2}{*}{$\begin{array}{c}2,3-\mathrm{BD}^{\mathrm{a}} \\
(\mathrm{g} / \mathrm{L} / \mathrm{h})\end{array}$} & \multirow{2}{*}{$\begin{array}{c}\mathrm{Y}_{2,3-\mathrm{BD}}{ }^{\mathrm{a}} \\
(\mathrm{g} / \mathrm{g})^{\mathrm{b}}\end{array}$} \\
\hline & $X_{1}$ & $X_{2}$ & $X_{3}$ & & & \\
\hline 1 & 37 & 5.50 & 3.0 & 76.90 & 1.71 & 0.41 \\
\hline 2 & 31 & 6.50 & 1.0 & 58.50 & 0.56 & 0.34 \\
\hline 3 & 31 & 5.50 & 3.0 & 80.20 & 1.64 & 0.48 \\
\hline 4 & 37 & 5.50 & 1.0 & 68.42 & 1.51 & 0.38 \\
\hline 5 & 39.0454 & 6.0 & 2.0 & 71.81 & 2.08 & 0.39 \\
\hline 6 & 34 & 6.0 & 3.6818 & 90.86 & 1.34 & 0.49 \\
\hline 7 & 34 & 6.8409 & 2.0 & 58.10 & 1.05 & 0.32 \\
\hline 8 & 34 & 6.0 & 2.0 & 75.45 & 1.45 & 0.43 \\
\hline 9 & 34 & 6.0 & 2.0 & 76.79 & 1.48 & 0.44 \\
\hline 10 & 31 & 5.50 & 1.0 & 73.01 & 0.71 & 0.41 \\
\hline 11 & 34 & 6.0 & 0.3182 & 72.70 & 1.36 & 0.40 \\
\hline 12 & 34 & 5.1591 & 2.0 & 66.57 & 0.67 & 0.32 \\
\hline 13 & 37 & 6.50 & 1.0 & 75.57 & 1.23 & 0.43 \\
\hline 14 & 37 & 6.50 & 3.0 & 84.53 & 1.61 & 0.48 \\
\hline 15 & 28.9546 & 6.0 & 2.0 & 55.72 & 0.55 & 0.47 \\
\hline 16 & 31 & 6.50 & 3.0 & 59.15 & 0.78 & 0.39 \\
\hline 17 & 34 & 6.0 & 2.0 & 76.08 & 1.46 & 0.43 \\
\hline 18 & 34 & 6.0 & 2.0 & 76.81 & 1.49 & 0.44 \\
\hline 19 & 34 & 6.0 & 2.0 & 76.10 & 1.46 & 0.43 \\
\hline 20 & 34 & 6.0 & 2.0 & 75.49 & 1.45 & 0.43 \\
\hline
\end{tabular}

${ }^{\mathrm{a}}$ Mean values of duplicates; ${ }^{\mathrm{b}}$ gram produced 2,3-BD per gram consumed glucose.

When 2,3-BD concentration $(Y)$ was used as a response, the response surface regression equation has a coefficient of determination $R^{2}=0.9659$, which means that this model fits the experimental data extremely well. The obtained results from the statistical analysis are presented in Table 8 .

Table 8. Estimated coded coefficients from the regression model for $2,3-\mathrm{BD}$ production in a threefactor CCD.

\begin{tabular}{ccccc}
\hline Source & Effect & Coefficient & $T$ Value & $p$ Value \\
\hline Constant & & 76.018 & 78.01 & $<0.001$ \\
$\mathrm{t}^{\circ} \mathrm{C}\left(X_{1}\right)$ & 9.024 & 4.512 & 6.98 & $<0.001$ \\
$\mathrm{pH}\left(X_{2}\right)$ & -5.129 & -2.565 & -3.97 & 0.003 \\
Aeration rate & 8.175 & 4.087 & 6.32 & $<0.001$ \\
$(\mathrm{vvm})\left(X_{3}\right)$ & -7.404 & -3.702 & -5.88 & $<0.001$ \\
$X_{1}^{2}$ & -8.416 & -4.208 & -6.69 & 0.001 \\
$X_{2}^{2}$ & 5.334 & 2.667 & 4.24 & 0.002 \\
$X_{3}^{2}$ & 12.585 & 6.292 & 7.45 & $<0.001$ \\
$X_{1} X_{2}$ & 2.400 & 1.200 & 1.42 & 0.186 \\
$X_{1} X_{3}$ & -1.515 & -0.757 & -0.90 & 0.391 \\
$X_{2} X_{3}$ & & &
\end{tabular}

Interaction terms $X_{1} X_{3}$ and $X_{2} X_{3}$ are not statistically significant $(p>0.05)$ and, after their exclusion, the second-degree polynomial equation takes the following form:

$$
Y=76.02+4.51 X_{1}-2.57 X_{2}+4.09 X_{3}-3.70 X_{1}^{2}-4.21 X_{2}^{2}+2.67 X_{3}^{2}+6.30 X_{1} X_{2}
$$

Response optimization predicts the maximum value of $93.77(\mathrm{~g} / \mathrm{L})$ for $Y(2,3-\mathrm{BD}$ maximum concentration) at the following conditions: temperature $\left(X_{1}\right), 37.82{ }^{\circ} \mathrm{C} ; \mathrm{pH}\left(X_{2}\right)$, 6.23; aeration flow $\left(X_{3}\right), 3.68 \mathrm{vvm}$. 


\subsubsection{Experimental Verification of the Model}

For the validation of the model (regression Equation (4)), we performed batch fermentation by $B$. licheniformis 24 in optimized media and process parameters. The results (mean values of three separate experiments) are presented in Figure 2. The highest obtained concentration of 2,3-BD was $91.23 \pm 2.9 \mathrm{~g} / \mathrm{L}$. This value is higher than all observed responses in the design matrix (Table 7) and is close to the predicted $93.77 \mathrm{~g} / \mathrm{L}$. Thus, the verification of the model was successful. Similarly, the overall achieved productivity of $1.94 \mathrm{~g} / \mathrm{L} / \mathrm{h}$ 2.3-BD and 2,3-BD yield of $0.488 \mathrm{~g} / \mathrm{g}$ ( $98 \%$ of the theoretical maximum of 0.5 ), also shows that the whole process is almost completely optimized for 2,3-BD production.

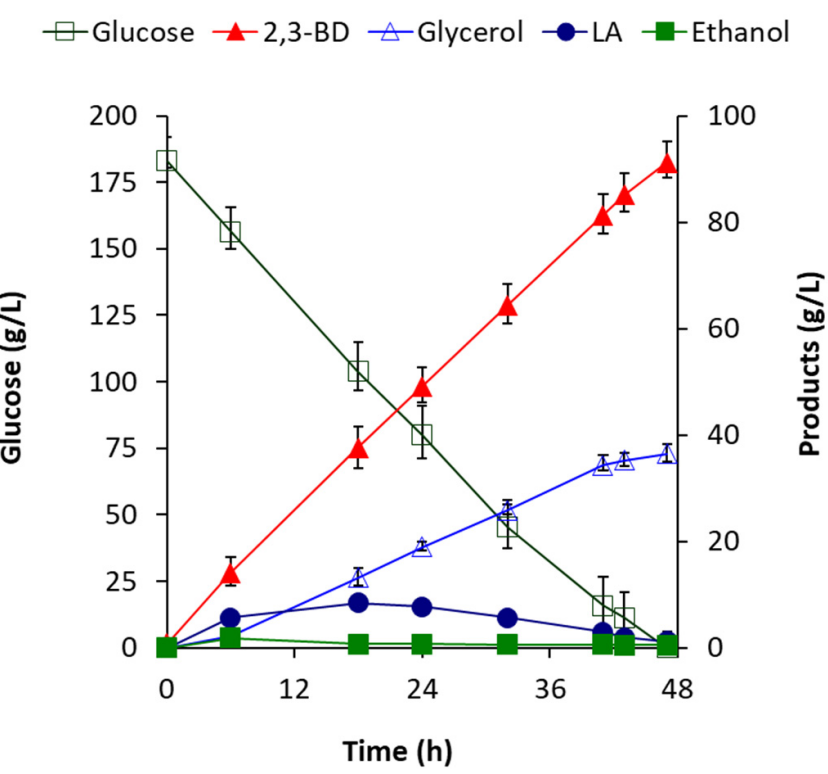

(a)

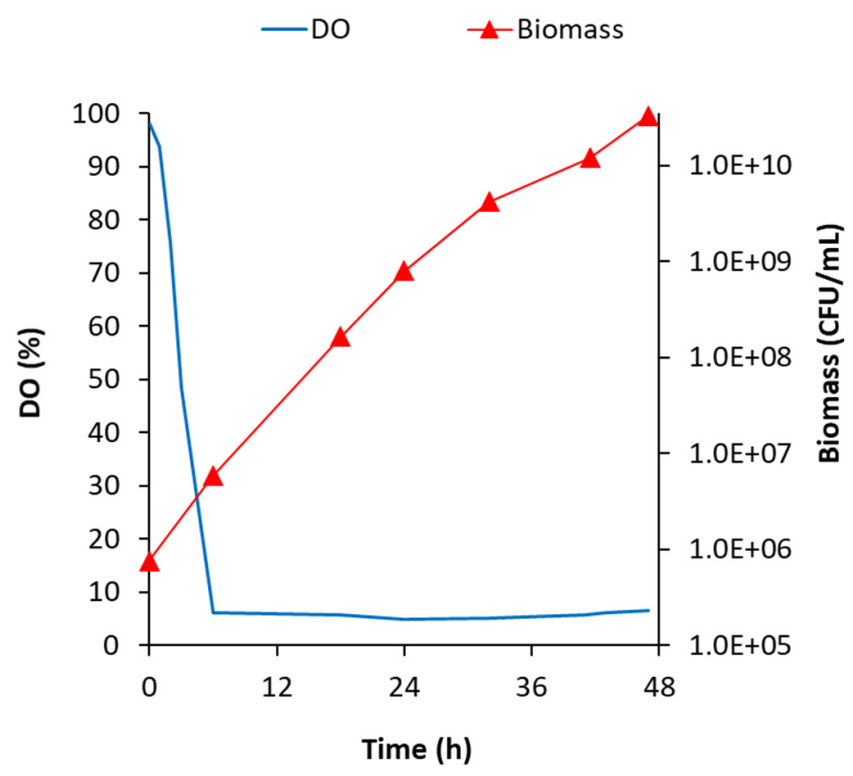

(b)

Figure 2. Batch fermentation of $200 \mathrm{~g} / \mathrm{L}$ of glucose by B. licheniformis 24 in optimized medium and process parameters. (a) Glucose consumption and products accumulation (triplicates). (b) Time course of the dissolved oxygen (DO) and biomass formation.

In these conditions, the main by-product of the fermentation was glycerol- $35.20 \mathrm{~g} / \mathrm{L}-$ as both glycerol and 2,3-BD increased their titers continuously during the process. The other soluble metabolites were accumulated in small quantities at the end of fermentation, including lactic acid, $1.2 \mathrm{~g} / \mathrm{L}$, and acetoin and ethanol in amounts less than $1 \mathrm{~g} / \mathrm{L}$. In the course of the fermentation, lactic acid achieved the highest concentration at the 18th $\mathrm{h}(8.37 \mathrm{~g} / \mathrm{L})$ and then slowly decreased. A similar profile was observed for ethanol; its accumulation reached a maximum of $1.8 \mathrm{~g} / \mathrm{L}$ at the 6th hour, then decreased to $0.5 \mathrm{~g} / \mathrm{L}$ at the end of the process (Figure 2a). Acetoin was formed only in the first few hours. Then, with the decrease in dissolved oxygen in the broth (Figure 2b), acetoin synthesis ceased until complete depletion of the carbon source. Glucose was entirely consumed after $47 \mathrm{~h}$ of fermentation (Figure 2a), whereas the D-isomer of 2,3-BD was sharply converted to acetoin (data not shown).

\subsection{Fed-Batch Process in Optimized Conditions}

To reveal the maximum tolerance of $B$. licheniformis 24 to 2,3-BD, which determines its maximum capabilities as a producer, a fed-batch process under the described optimized conditions was performed. The highest achieved concentration of 2,3-BD was $138.8 \mathrm{~g} / \mathrm{L}$, with 2,3-BD productivity of $1.16 \mathrm{~g} / \mathrm{L} / \mathrm{h}$ and yield of $0.478 \mathrm{~g} / \mathrm{g}$. High product inhibition was observed at concentrations above $100 \mathrm{~g} / \mathrm{L}$, leading to a decrease in glucose consumption 
rate. Glucose fermentation ceases completely after the 140th hour. The main fermentation by-product was glycerol, reaching its maximum of $45.38 \mathrm{~g} / \mathrm{L}$ after $120 \mathrm{~h}$ of fermentation. Lactic acid and ethanol were accumulated temporarily in the broth and were in insignificant concentrations at the end of the process (Figure 3a). Acetoin was accumulated after the 70th hour of fermentation, when the DO concentration slightly increased from 6 to $14 \%$ at the end of the process (Figure $3 b$ ).

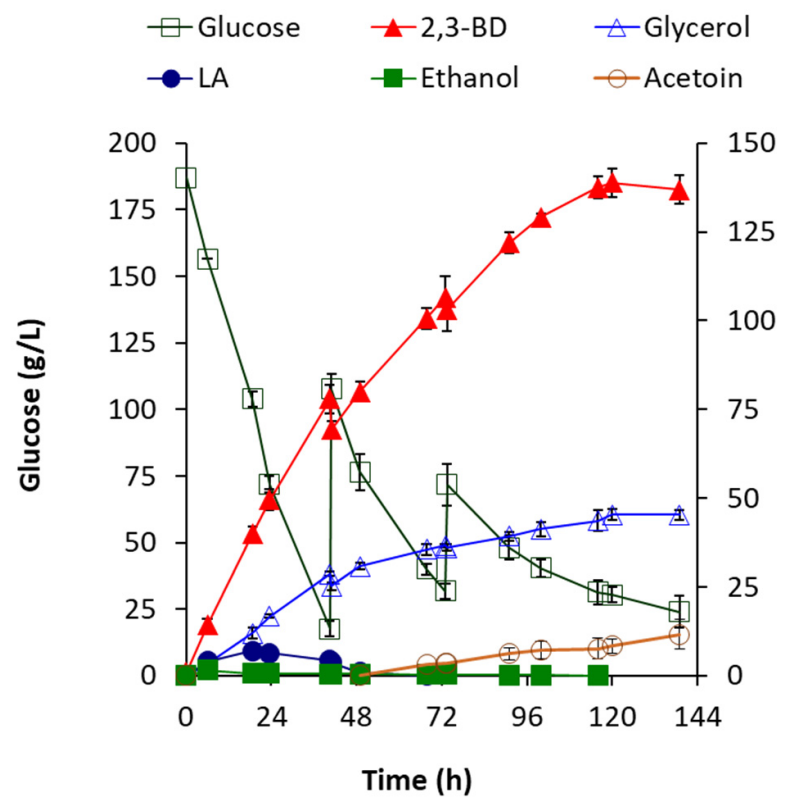

(a)

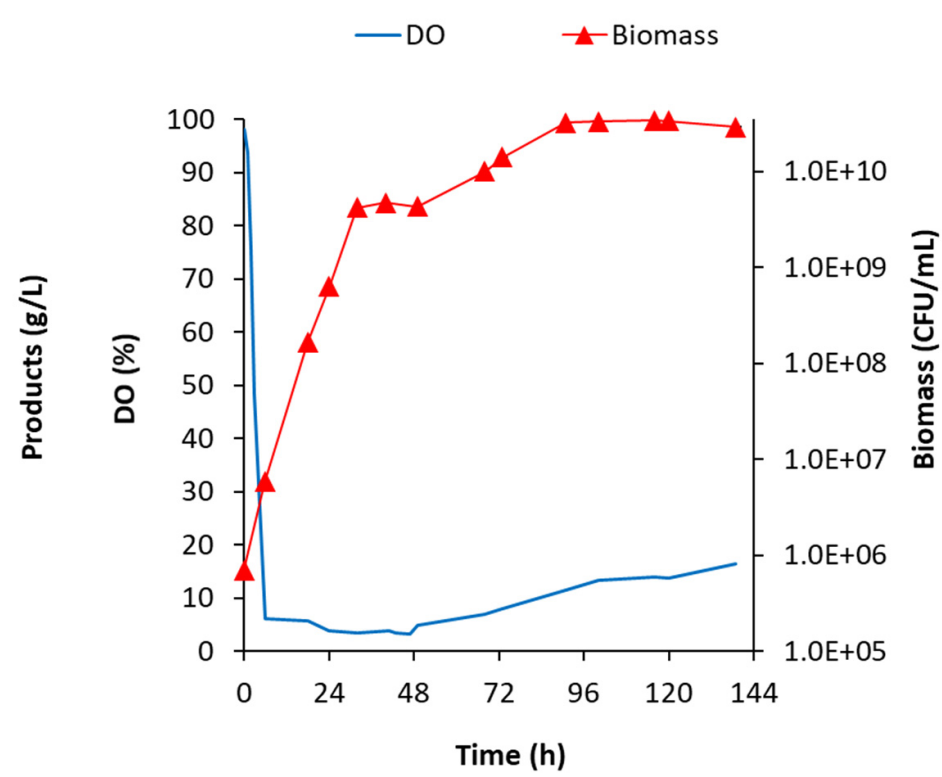

(b)

Figure 3. Fed-batch fermentation of glucose by B. licheniformis 24 in optimized medium and process parameters. (a) Glucose consumption and products accumulation (mean values of duplicates). (b) Time course of the dissolved oxygen (DO) and biomass formation.

\section{Discussion}

For more than a decade, the fermentation of 2,3-BD has been the subject of continuous laboratory research, including the use of different types of natural and modified producers, a variety of substrates, innovative methods to control the process and new, promising ways of product extraction [5,33]. At present, however, this process has never been successfully commercialized. The reasons lie in the high price of the substrates, the pathogenic nature of the best producers and the expensive extraction of the product from the fermentation mixture (further discouraged by significant losses).

B. licheniformis 24 has several advantages as a producer of 2,3-BD; it is non-pathogenic, has a broad substrate spectrum, possesses a high consumption rate and high yield, regardless of the substrate [18]. The present study establishes the strain as a super-producer of 2,3-BD with a future industrial application by employing complex optimization via series of Plackett-Burman design and CCD experiments.

The application of the Plackett-Burman design showed that among the components of the nutrient medium with significant influence, the yeast extract, $\mathrm{K}_{2} \mathrm{HPO}_{4}, \mathrm{MgSO}_{4}$ and tryptone had the most pronounced positive effect on 2,3-BD production. The addition of corn steep liquor and MOPS had a negative impact on 2,3-BD production and these two compounds were excluded from the media. This observation is in agreement with Song et al. [16], who revealed that corn steep liquor is less suitable than yeast extract as a nitrogen source for B. licheniformis. Unlike P. polymyxa [32], B. licheniformis does not need MOPS, which makes the nutrient medium cheaper. The establishment of the optimal values of the components with the greatest impact on 2,3-BD production was achieved by 
CCD experiments. The computed optimal values were: yeast extract, $13.38 \mathrm{~g} / \mathrm{L} ; \mathrm{K}_{2} \mathrm{HPO}_{4}$, $4.20 \mathrm{~g} / \mathrm{L}$; tryptone, $6.41 \mathrm{~g} / \mathrm{L} ; \mathrm{MgSO}_{4}, 0.32 \mathrm{~g} / \mathrm{L}$. In this experiment, as revealed by the screening design, yeast extract and $\mathrm{K}_{2} \mathrm{HPO}_{4}$ had the highest impact on 2,3-BD production. However, $\mathrm{MgSO}_{4}$ did not affect the response in the second experimental range. The response surface graph revealed that the yeast extract is the preferred nitrogen source, but a total concentration of yeast extract and tryptone above $20 \mathrm{~g} / \mathrm{L}$ led to a decrease in 2,3-BD formation (Figure 1a).

A specific characteristic feature of B. licheniformis 24 is the production of glycerol as the main by-product of glucose fermentation. This finding distinguishes $B$. licheniformis 24 from most of the 2,3-BD-producing bacilli. Importantly, due to glycerol formation, the acidity of the medium changes slightly during the process and the fermentation could be performed without any $\mathrm{pH}$ control. Unlike other strains of the species, B. licheniformis 24 does not produce formic acid at all. The accumulation of the toxic formic acid [33] remains a serious problem against the industrial application of $B$. licheniformis, as its amount could reach between $29.1 \mathrm{~g} / \mathrm{L}$ and $42 \mathrm{~g} / \mathrm{L}$ at the end of the process [16,19].

Therefore, an important achievement of the present study is the clarification of the process parameters that are suitable for maximum production of 2,3-BD by a strain, producing glycerol as a main by-product. To obtain the highest 2,3-BD concentration, according to maximized regression equation (4), the following process parameters were determined: temperature, $37.82{ }^{\circ} \mathrm{C} ; \mathrm{pH}, 6.23$; airflow rate, $3.68 \mathrm{vvm}$. The temperature was found as the parameter with the highest impact, but the estimated optimal values were quite different for 2,3-BD concentration, 2,3-BD productivity and 2,3-BD yield. Indeed, the higher temperatures accelerate glucose consumption, which results in higher 2,3-BD productivity. For example, at a constant $\mathrm{pH}$ of 6.0 and aeration rate of $2 \mathrm{vvm}$, an increase in temperature from $29{ }^{\circ} \mathrm{C}$ to $39{ }^{\circ} \mathrm{C}$ raised 2,3-BD productivity from 0.55 to $2.08 \mathrm{~g} / \mathrm{L} / \mathrm{h}$. However, due to higher glycerol formation, 2,3-BD yield decreased from 0.47 to $0.39 \mathrm{~g} / \mathrm{g}$ (Figure 4a). With a glucose consumption rate increase (from 1.35 to $4.92 \mathrm{~g} / \mathrm{L} / \mathrm{h}$ ), glycerol accumulation rose from 2.42 to $37.25 \mathrm{~g} / \mathrm{L}$ (Figure $4 \mathrm{~b}$ ); therefore, at higher temperatures and low aeration, glycerol production appears to be favored.

Conversely, the higher aeration levels favored 2,3-BD concentration increase and 2,3$\mathrm{BD}$ yield and did not possess any significant effect on 2,3-BD productivity (Figure 5a). Regarding glucose consumption and glycerol accumulation, the increase of aeration definitely affected the process in the opposite way with respect to the temperature rise (Figure $5 b$ ).

According to Li et al. [19] and Rebecchi et al. [34], acetoin synthesis is strongly influenced by oxygen availability. Under fully aerobic conditions, the oxygen is the electron acceptor for NAD+ regeneration and acetoin reduction to 2,3-BD does not occur. The observation that acetoin production is greater at highly aerobic conditions determined the development of complex two-stage aeration regimes in the processes for obtaining 2,3-BD by $B$. licheniformis $[16,19,34,35]$. On the contrary, when the oxygen supply is insufficient, the appropriate regeneration of co-factors such as NAD+ cannot be achieved by electron transfer onto oxygen, but, alternatively, NAD+ regeneration could be achieved by the reduction of dihydroxyacetone phosphate to glycerol-3-phosphate, which is then dephosphorylated yielding glycerol.

It turns out that B. licheniformis strain 24 is an extremely aerobic 2,3-BD producer and is capable to consume huge oxygen amounts. As it was shown in Figure $2 b$, the retention of dissolved oxygen in the medium remained constantly low, after the 6th hour, till the end of fermentation. This high oxygen consumption prevented acetoin formation even at the highest tested aeration levels. However, glycerol synthesis cannot be avoided even at high aeration levels. 


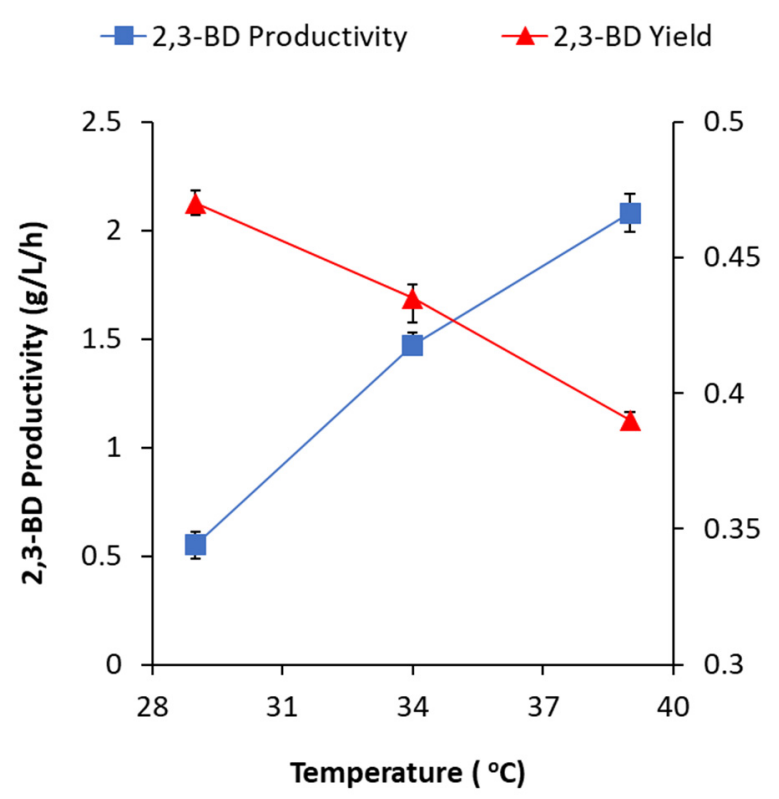

(a)

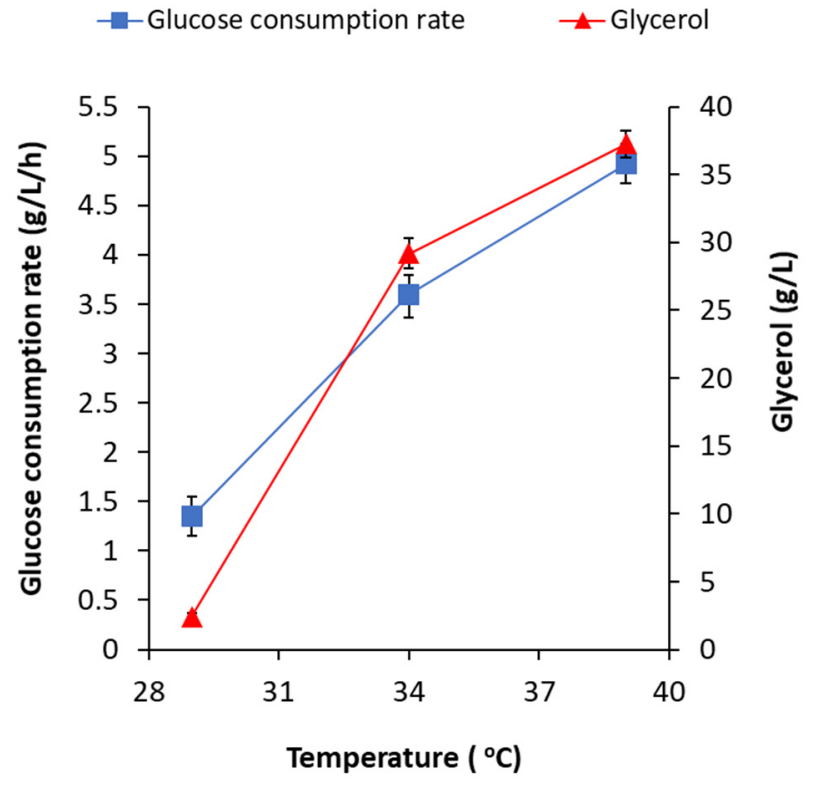

(b)

Figure 4. Influence of temperature on the fermentation of $200 \mathrm{~g} / \mathrm{L}$ glucose by B. licheniformis 24 on (a) 2,3-BD productivity and 2,3-BD yield and (b) glucose consumption rate and glycerol formation. Fermentations were carried out at a $\mathrm{pH}$ of 6.00 and an aeration rate of $2 \mathrm{vvm}$. Mean values of at least two separate experiments are presented.

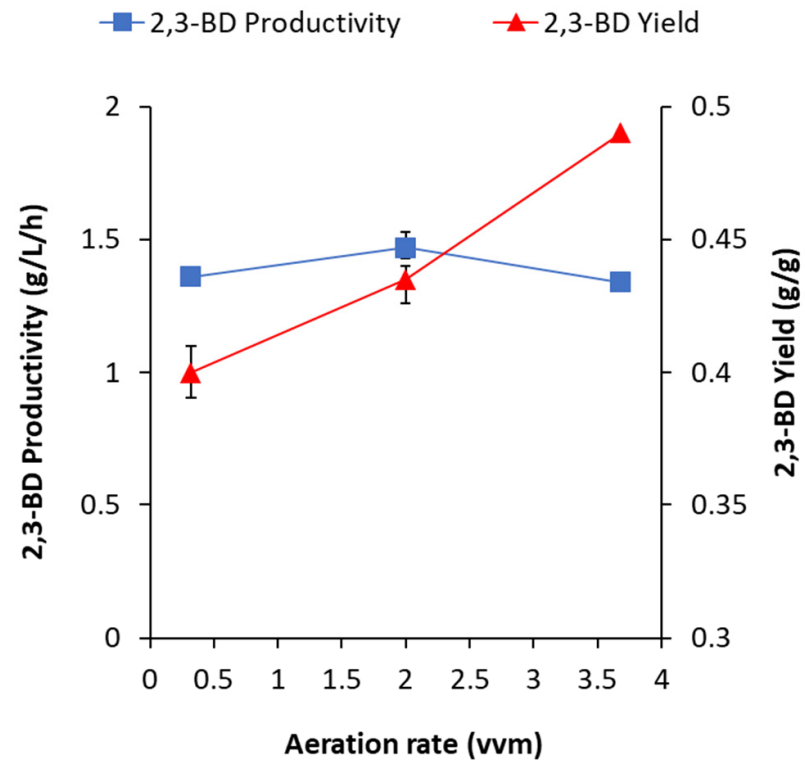

(a)

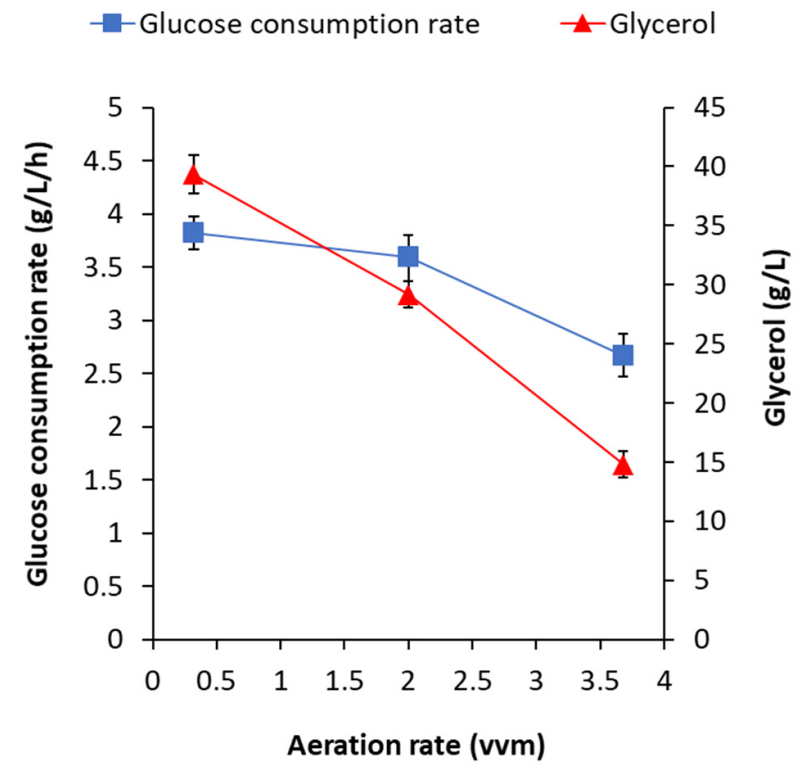

(b)

Figure 5. Influence of aeration rate on the fermentation of $200 \mathrm{~g} / \mathrm{L}$ glucose by B. licheniformis 24 on (a) 2,3-BD productivity and 2,3-BD yield and (b) glucose consumption rate and glycerol formation. Fermentations were carried out at a $\mathrm{pH}$ of 6.00 and temperature of $34^{\circ} \mathrm{C}$. Presented are mean values of at least two separate experiments.

$\mathrm{pH}$ changes affect 2,3-BD production to a lesser extent. At lower $\mathrm{pH}$ (5.16), acetoin appeared as the main by-product, reaching concentrations of $28.64 \mathrm{~g} / \mathrm{L}$. Acetoin is accumulated at a low glucose consumption rate, in this case, at conditions combining lower $\mathrm{pH}$ $(\leq 5.5)$ and lower temperature $\left(\leq 31^{\circ} \mathrm{C}\right)$. This positive effect of the high consumption rates 
of sugars (glucose, cellobiose and mannose) on 2,3-BD production at the expense of acetoin was always observed in B. licheniformis 24 [18].

The other significant by-product, glycerol, was not formed at lower $\mathrm{pH}$ (5.16), but increased at a $\mathrm{pH}$ of 6.0. However, Raspoet et al. [27] showed that the effect of $\mathrm{pH}$ on glycerol produced is strain specific. Expectedly, lactic acid is accumulated in the highest amounts, $14.11 \mathrm{~g} / \mathrm{L}$, in the process with a $\mathrm{pH}$ of 6.84 (Figure 6).

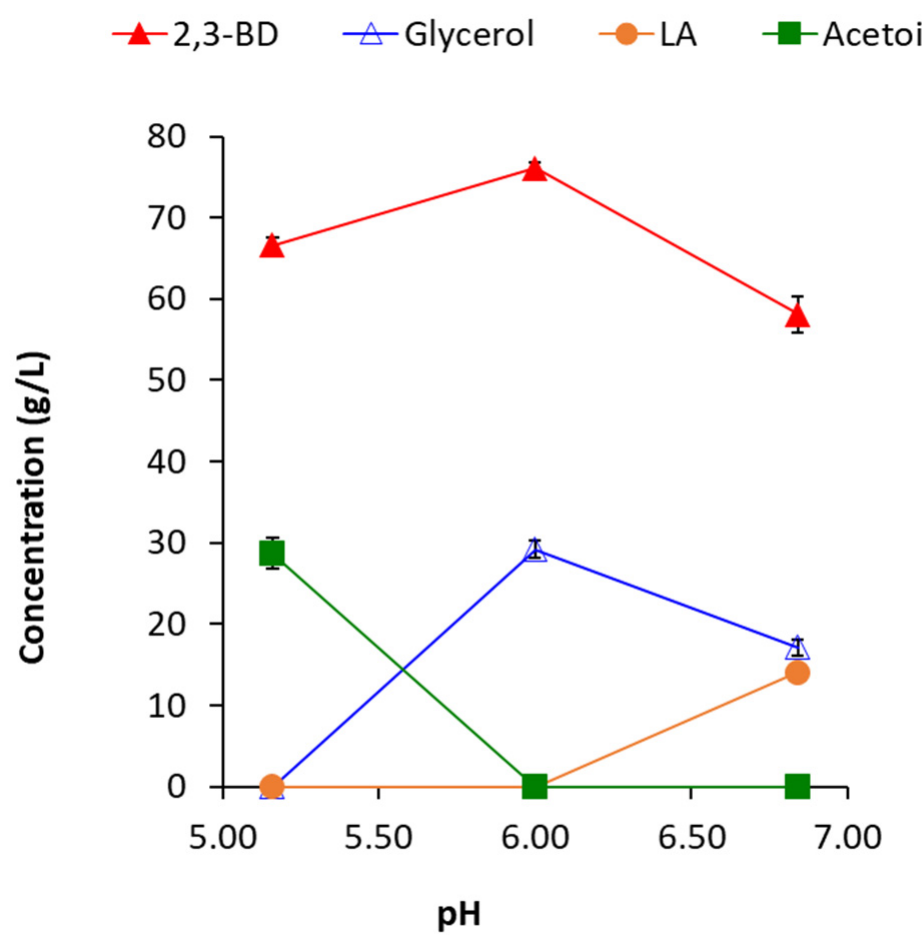

Figure 6. Influence of $\mathrm{pH}$ on product formation in the fermentation of $200 \mathrm{~g} / \mathrm{L}$ of glucose by $B$. licheniformis 24 . Fermentations were carried out at $\mathrm{t}=34^{\circ} \mathrm{C}$ and aeration rate of $2 \mathrm{vvm}$. Mean values of at least two separate experiments are presented.

B. licheniformis 24 produces 2,3-BD in two isomeric forms, meso-2,3-BD and D-2,3-BD, in a ratio of 1.6:1-1:1. It has not been observed that the ratio depends on the substrate used, but it seems to depend on the total concentration of 2,3-BD produced. For example, at the beginning of each fermentation, the meso-form slightly prevailed, followed by equalization of the ratio at a total concentration of $80-90 \mathrm{~g} / \mathrm{L}$ of 2,3-BD (Figure 7a). This occurrence was observed in all batch processes. However, in the fed-batch process with optimized parameters, after the 70th $\mathrm{h}$, the ratio changed again in favor of the meso-form and, by the end of the process, from 1.05:1, it became 1.23:1 (Figure 7b). A possible explanation is the production of acetoin during this period (Figure 3a), which was not observed in any of the batch processes when the carbon source was available. On the other hand, upon the complete depletion of the substrate, under the action of butanediol dehydrogenase $\mathrm{BDH}$, the D-form was rapidly converted to acetoin, while the meso-form decreased slowly and was converted to acetoin only partially.

The effect of the presented complex optimization of medium composition and process parameters is the most obvious when the batch processes are compared before and after optimizations. The application of optimized parameters increased the maximal concentration of 2,3-BD by $28.9 \%$, from $70.8 \mathrm{~g} / \mathrm{L}$, obtained without optimization [18], to $91.23 \mathrm{~g} / \mathrm{L}$. The yield increased by $6.8 \%$, from $0.457 \mathrm{~g} / \mathrm{g}$ to $0.488 \mathrm{~g} / \mathrm{g}$ substrate. Notably, the productivity increased more than 5 -fold, from $0.38 \mathrm{~g} / \mathrm{L} / \mathrm{h}$ to $1.94 \mathrm{~g} / \mathrm{L} / \mathrm{h}$. 


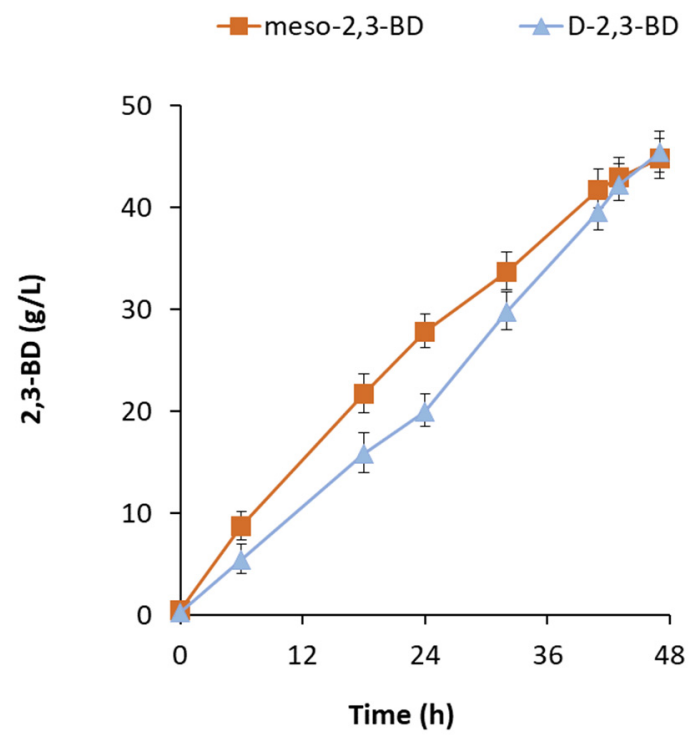

(a)

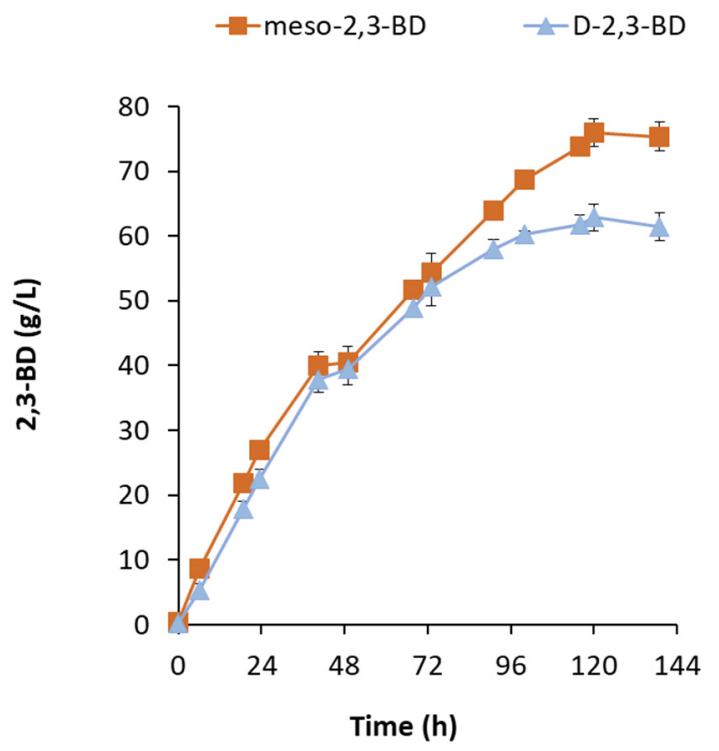

(b)

Figure 7. Production of meso- and D-2,3-BD by Bacillus licheniformis 24: (a) in batch fermentation of $200 \mathrm{~g} / \mathrm{L}$ of glucose and (b) in fed-batch glucose fermentation.

After performing all the steps of optimization and validation, we conducted a fedbatch process, which aimed to reveal the full potential, or the upper limit, of the strain as a producer of 2,3-BD. The obtained 2,3-BD concentration of $138.8 \pm 4.3 \mathrm{~g} / \mathrm{L}$, the productivity of $1.16 \mathrm{~g} / \mathrm{L} / \mathrm{h}$ and the yield, close to the theoretical $(0.479 \mathrm{~g} / \mathrm{g})$, ranks B. licheniformis 24 among the best non-pathogenic producers. Our results are very similar to the results presented by Jurchescu et al. [20] and obtained by the use of B. licheniformis DSM 8785: 2,3-BD concentration of $144.7 \mathrm{~g} / \mathrm{L}$ and productivity of $1.14 \mathrm{~g} / \mathrm{L} / \mathrm{h}$. A comparison of these results reveals that these values are probably the highest that can be obtained using the species $B$. licheniformis and comprise its maximum capabilities as a 2,3-BD producer. Compared to the best pathogenic producers as Klebsiella pneumoniae or K. oxytoca, it is obvious that they have comparable tolerance to 2,3-BD and produce relatively equal quantities of 2,3-BD, reaching $150 \mathrm{~g} / \mathrm{L}$. However, Klebsiella strains achieve this concentration up to four times faster [36-38]. Therefore, the low productivity continues to be an obstacle for industrial application of even the most successful non-pathogenic 2,3-BD producers of the species B. licheniformis.

\section{Conclusions}

Non-pathogenic producers of 2,3-BD are preferred for industrial applications. Here we present a complex optimization of the nutrient medium and process parameters for the production of 2,3-BD with the purpose to disclose and validate the suitability of the strain B. licheniformis 24 for commercialization. All optimization steps were carried out in course of batch processes, since this performance enables the optimization of many more factors, compared to fed-batch mode. The high final titer of 2,3-BD and the high yield from glucose allow the evaluation of the strain as one of the best producers of 2,3-BD. Although very promising, the focus of future research with this strain should be on improving its 2,3-BD productivity, which can be significantly increased, but only at the expense of reducing the final 2,3-BD concentration. Therefore, much effort is still needed to address this issue, which is a common problem for all non-pathogenic producers of 2,3-BD. 
Author Contributions: Conceptualization, K.P. and P.P.; methodology, K.P.; investigation, L.T. and D.G.; writing-original draft preparation, K.P.; writing-review and editing, P.P. All authors have read and agreed to the published version of the manuscript.

Funding: This research was funded by grant DN 17/1 from the National Scientific Fund, Ministry of Education and Science, Republic of Bulgaria, and grant DCM \#577 from the Ministry of Education and Science under the National Research Program "Young scientists and postdoctoral students".

Institutional Review Board Statement: Not applicable.

Informed Consent Statement: Not applicable.

Data Availability Statement: Not applicable.

Conflicts of Interest: The authors declare no conflict of interest. The funders had no role in the design of the study; in the collection, analyses, or interpretation of data; in the writing of the manuscript; or in the decision to publish the results.

\section{References}

1. Song, C.W.; Park, J.M.; Chung, S.C.; Lee, S.Y.; Song, H. Microbial production of 2,3-butanediol for industrial applications. J. Ind. Microbiol. Biotechnol. 2019, 46, 1583-1601. [CrossRef]

2. Parate, R.D.; Rode, C.V.; Dharne, M.S. 2,3-Butanediol Production from Biodiesel Derived Glycerol. Curr. Environ. Eng. 2018, 5, 4-12. [CrossRef]

3. Tinôco, D.; Borschiver, S.; Coutinho, P.L.; Freire, D.M.G. Technological development of the bio-based 2,3-butanediol process. Biofuels Bioprod. Biorefining 2021, 15, 357-376. [CrossRef]

4. $\quad$ Lee, J.H.; Lee, D.Y.; Lee, S.K.; Kim, H.R.; Chun, Y.; Yoo, H.Y.; Kwak, H.S.; Park, C.; Lee, J.H.; Kim, S.W. Development of 2,3-Butanediol Production Process from Klebsiella aerogenes ATCC 29007 Using Extracted Sugars of Chlorella pyrenoidosa and Biodiesel-Derived Crude Glycerol. Processes 2021, 9, 517. [CrossRef]

5. Hakizimana, O.; Matabaro, E.; Lee, B.H. The current strategies and parameters for the enhanced microbial production of 2,3-butanediol. Biotechnol. Rep. 2020, 25, e00397. [CrossRef]

6. He, Y.; Chen, F.; Sun, M.; Gao, H.; Guo, Z.; Lin, H.; Chen, J.; Jin, W.; Yang, Y.; Zhang, L.; et al. Efficient (3S)-Acetoin and (2S,3S)-2,3-Butanediol Production from meso-2,3-Butanediol Using Whole-Cell Biocatalysis. Molecules 2018, 23, 691. [CrossRef] [PubMed]

7. Mitrea, L.; Călinoiu, L.-F.; Martău, G.-A.; Szabo, K.; Teleky, B.-E.; Mureșan, V.; Rusu, A.-V.; Socol, C.-T.; Vodnar, D.-C. Poly(vinyl alcohol)-Based Biofilms Plasticized with Polyols and Colored with Pigments Extracted from Tomato By-Products. Polymers 2020, 12, 532. [CrossRef] [PubMed]

8. Koutinas, A.A.; Yepez, B.; Kopsahelis, N.; Freire, D.M.G.; de Castro, A.M.; Papanikolaou, S.; Kookos, I.K. Techno-economic evaluation of a complete bioprocess for 2,3-butanediol production from renewable resources. Bioresour. Technol. 2016, $204,55-64$. [CrossRef]

9. Samoilov, V.; Ni, D.; Goncharova, A.; Zarezin, D.; Kniazeva, M.; Ladesov, A.; Kosyakov, D.; Bermeshev, M.; Maximov, A. BioBased Solvents and Gasoline Components from Renewable 2,3-Butanediol and 1,2-Propanediol: Synthesis and Characterization. Molecules 2020, 25, 1723. [CrossRef]

10. Häßler, T.; Schieder, D.; Pfaller, R.; Faulstich, M.; Sieber, V. Enhanced fed-batch fermentation of 2,3-butanediol by Paenibacillus polymyxa DSM 365. Bioresour. Technol. 2012, 124, 237-244. [CrossRef]

11. Li, J.; Wang, W.; Ma, Y.H.; Zeng, A.P. Medium optimization and proteome analysis of (R,R)-2,3-butanediol production by Paenibacillus polymyxa ATCC 12321. Appl. Microbiol. Biotechnol. 2013, 97, 585-597. [CrossRef] [PubMed]

12. Liu, Z.; Qin, J.; Gao, C.; Hua, D.; Ma, C.; Li, L.; Wang, Y.; Xu, P. Production of (2S,3S)-2,3-butanediol and (3S)-acetoin from glucose using resting cells of Klebsiella pneumoniae and Bacillus subtilis. Bioresour. Technol. 2011, 102, 10741-10744. [CrossRef] [PubMed]

13. Wang, D.; Oh, B.R.; Lee, S.; Kim, D.-H.; Joe, M.-H. Process optimization for mass production of 2,3-butanediol by Bacillus subtilis CS13. Biotechnol. Biofuels 2021, 14, 15. [CrossRef]

14. Zhang, Y.; Li, S.; Liu, L.; Wu, J. Acetoin production enhanced by manipulating carbon flux in a newly isolated Bacillus amyloliquefaciens. Bioresour. Technol. 2013, 130, 256-260. [CrossRef]

15. Yang, T.; Rao, Z.; Zhang, X.; Lin, Q.; Xia, H.; Xu, Z.; Yang, S. Production of 2,3-butanediol from glucose by GRAS microorganism Bacillus amyloliquefaciens. J. Basic Microbiol. 2011, 51, 650-658. [CrossRef] [PubMed]

16. Song, C.W.; Rathnasingh, C.; Park, J.M.; Lee, J.; Song, H. Isolation and evaluation of Bacillus strains for industrial production of 2,3-butanediol. J. Microbiol. Biotechnol. 2018, 28, 409-417. [CrossRef]

17. Kallbach, M.; Horn, S.; Kuenz, A.; Prusse, U. Screening of novel bacteria for the 2,3-butanediol production. Appl. Microbiol. Biotechnol. 2017, 101, 1025-1033. [CrossRef] [PubMed]

18. Petrova, P.; Petlichka, S.; Petrov, K. New Bacillus spp. with potential for 2,3-butanediol production from biomass. J. Biosci. Bioeng. 2020, 130, 20-28. [CrossRef] [PubMed] 
19. Li, L.; Zhang, L.; Li, K.; Wang, Y.; Gao, C.; Han, B.; Ma, C.; Xu, P. A newly isolated Bacillus licheniformis strain thermophilically produces 2,3-butanediol, a platform and fuel bio-chemical. Biotechnol. Biofuels 2013, 6, 123. [CrossRef]

20. Jurchescu, I.M.; Hamann, J.; Zhou, X.; Ortmann, T.; Kuenz, A.; Prusse, U.; Lang, S. Enhanced 2,3-butanediol production in fed batch cultures of free and immobilized Bacillus licheniformis DSM 8785. Appl. Microbiol. Biotechnol. 2013, 97, 6715-6723. [CrossRef]

21. Qiu, Y.; Zhang, J.; Li, L.; Wen, Z.; Nomura, C.T.; Wu, S.; Chen, S. Engineering Bacillus licheniformis for the production of meso-2,3-butanediol. Biotechnol. Biofuels 2016, 9, 117. [CrossRef]

22. Perego, P.; Converti, A.; del Borghi, M. Effects of temperature, inoculum size and starch hydrolyzate concentration on butanediol production by Bacillus licheniformis. Bioresour. Technol. 2003, 89, 125-131. [CrossRef]

23. Li, L.X.; Li, K.; Wang, K.; Chen, C.; Gao, C.; Ma, C.Q.; Xu, P. Efficient production of 2,3-butanediol from corn stover hydrolysate by using a thermophilic Bacillus licheniformis strain. Bioresour. Technol. 2014, 170, 256-261. [CrossRef] [PubMed]

24. Li, L.X.; Chen, C.; Li, K.; Wang, Y.; Gao, C.; Ma, C.Q.; Xu, P. Efficient simultaneous saccharification and fermentation of inulin to 2,3-butanediol by thermophilic Bacillus licheniformis ATCC 14580. Appl. Environ. Microbiol. 2014, 80, 6458-6464. [CrossRef] [PubMed]

25. Ge, Y.S.; Li, K.; Li, L.X.; Gao, C.; Zhang, L.J.; Ma, C.Q.; Xu, P. Contracted but effective: Production of enantiopure 2,3-butanediol by thermophilic and GRAS Bacillus licheniformis. Green Chem. 2016, 18, 4693-4703. [CrossRef]

26. Nilegaonkar, S.; Bhosale, S.B.; Kshirsagar, D.C.; Kapidi, A.H. Production of 2,3-butanediol from glucose by Bacillus licheniformis. World J. Microbiol. Biotechnol. 1992, 8, 378-381. [CrossRef] [PubMed]

27. Raspoet, D.; Pot, B.; De Deyn, D.; De Vos, P.; Kersters, K.; De Ley, J. Differentiation Between 2,3-Butanediol Producing Bacillus licheniformis and B. polymyxa Strains by Fermentation Product Profiles and Whole-Cell Protein Electrophoretic Patterns. Syst. Appl. Microbiol. 1991, 14, 1-7. [CrossRef]

28. Thanh, T.N.; Jurgen, B.; Bauch, M.; Liebeke, M.; Lalk, M.; Ehrenreich, A.; Evers, S.; Maurer, K.H.; Antelmann, H.; Ernst, F.; et al. Regulation of acetoin and 2,3-butanediol utilization in Bacillus licheniformis. Appl. Microbiol. Biotechnol. 2010, 87, $2227-2235$. [CrossRef]

29. Okonkwo, C.C.; Ujor, V.; Ezeji, T.C. Investigation of relationship between 2,3-butanediol toxicity and production during growth of Paenibacillus polymyxa. New Biotechnol. 2017, 34, 23-31. [CrossRef]

30. Reddy, L.V.A.; Wee, Y.-J.; Yun, J.-S.; Ryu, H.-W. Optimization of alkaline protease production by batch culture of Bacillus sp. RKY3 through Plackett-Burman and response surface methodological approaches. Bioresour. Technol. 2008, 99, 2242-2249. [CrossRef]

31. De Castro, R.J.S.; Sato, H.H. Production and biochemical characterization of protease from Aspergillus oryzae: An evaluation of the physical-chemical parameters using agroindustrial wastes as supports. Biocatal. Agric. Biotechnol. 2014, 3, 20-25. [CrossRef]

32. Okonkwo, C.C.; Ujor, V.C.; Mishra, P.K.; Ezeji, T.C. Process Development for Enhanced 2,3-Butanediol Production by Paenibacillus polymyxa DSM 365. Fermentation 2017, 3, 18. [CrossRef]

33. Ji, X.J.; Huang, H.; Ouyang, P.K. Microbial 2,3-butanediol production: A state-of the art review. Biotechnol. Adv. 2011, 29, 351-364. [CrossRef]

34. Rebecchi, S.; Pinelli, D.; Zanaroli, G.; Fava, F.; Frascari, D. Effect of oxygen mass transfer rate on the production of 2,3-butanediol from glucose and agro-industrial byproducts by Bacillus licheniformis ATCC9789. Biotechnol. Biofuels 2018, 11, 145. [CrossRef]

35. Li, L.; Wei, X.; Yu, W.; Wen, Z.; Chen, S. Enhancement of acetoin production from Bacillus licheniformis by 2,3-butanediol conversion strategy: Metabolic engineering and fermentation control. Process Biochem. 2017, 57, 35-42. [CrossRef]

36. Kim, D.K.; Park, J.M.; Song, H. Kinetic modeling of substrate and product inhibition for 2,3-butanediol production by Klebsiella oxytoca. Biochem. Eng. J. 2016, 114, 94-100. [CrossRef]

37. Ma, C.; Wang, A.; Qin, J.; Li, L.; Ai, X.; Jiang, T.; Tang, H.; Xu, P. Enhanced 2,3-butanediol production by Klebsiella pneumonia SDM. Appl. Microbiol. Biotechnol. 2009, 82, 49-57. [CrossRef]

38. Mitrea, L.; Vodnar, D.C. Klebsiella pneumoniae-A Useful Pathogenic Strain for Biotechnological Purposes: Diols Biosynthesis under Controlled and Uncontrolled pH Levels. Pathogens 2019, 8, 293. [CrossRef] 